\title{
Detection of Oxamyl and Imidacloprid Pesticide residues in Some Iraqi Vegetables
}

\author{
"Maad N. Mahdi ${ }^{1}$, Ahmed J. Mohammed ${ }^{2}$ \\ ${ }^{1}$ Ministry of Agriculture, Directorate of Seed Testing and Certification, Iraq. \\ ${ }^{2}$ Department of Biology, Collage of Science, University of Baghdad, Iraq. \\ Corresponding Author: Maad N. Mahdi
}

\begin{abstract}
Application of pesticide on vegetables will protect them from pest injury, but in another hand will hold pesticide residues inside vegetables. These residues have harmful effect against all consumers. Detection about pesticide residues has been carried out for some Iraqi vegetables (tomato, cucumber, eggplant, and zucchini) by using Gas Chromatography/Mass Spectroscopy (GC/MS). QuEChERS method has been applied for extraction pesticide residues from targeted vegetables. The GC/MS has been carried out for distinguish the vegetables that are suffering from hyper concentration in pesticide residues more than maximum residues limits (MRLs) that is determinant by codex alimentarius. GC/MS analysis that is carried out reviled the existence of only bi-products belong to imidacloprid and oxamyl pesticides. The active ingredients of both pesticides degraded efficiently and there is no ability to trace them back. Some of the bi-products represent additives add to improve the ability of pesticides in killing pest. Some of those bi-products have toxicity when they combine with other kinds of components. The samples collected from two sites, the time of collection are beginning, mid, and end of month. The months that elected for collection samples are August, September, October, and November. The detection revealed that November is the best month regarding pesticide residues.
\end{abstract}

Keywords: Imidacloprid, Oxamyl, Pesticide residues, QuEChERS, Vegetables

\section{Introduction}

Pesticide is defined as any substances or mixture of substances planned for avoiding, destroying, repelling, or mitigating any pests [1]. Pesticide residues defined as any substance or mixture of material in food for man or forage for animals resulting from the use of pesticide including any determinant derivatives, such as degradation and conversion products, metabolites, reaction products and uncleanness considered to have significant toxic effect [2]. There are two kinds of pesticide residues, bound and conjugated pesticide residues. A soil bound residue is "the un extractable and chemically un identifiable pesticide residues outstanding in fulvic acid, humic acid, and humin fraction after exhaustive sequential extraction with non polar organic and polar solvents". Conjugate pesticide residues are reflect more polar and less lipophlic than the parent pesticide molecules, and as such are therefore more basically could take out from animals and plants [3]. Agriculture in the world has altered greatly in the past one hundred years. Many farmers follow high yield by using low cost energy, plentiful water supply, efficient chemical fertilizers and pesticides [4]. Pesticide play as great value in the high productivity accomplished in agriculture through the control of plant or animal life pests. Although pesticides have advantages, some have defect, such as potential toxicity to human and other desired species. Exposure of general population to pesticide most generally occurs through consuming treated food sources [5]. Despite, good diet contain high percentage of vegetables and fruits show primary factor for reducing the risk of gastrointestinal and breast cancer disease, pesticide residues on vegetables forming possible danger to consumers and have adverse effect on human health [6]. Chemical pesticides are used extremely and regardless to manufacturing instructions. Moreover, $30 \%$ of pesticides soled in developing countries do not confront internationally quality standards [7]. Gas and liquid chromatography (GC and LC) coupled to sophisticated mass spectrometry (MS) instrument are among the most powerful analytical tools currently accessible for surveillance of pesticides in food [8].

\section{Materials And Methods}

\section{Apparatus}

The (Table 1) below shows apparatus that are used for detection process of pesticide residues in targeted vegetables 
Table (1) show apparatus

\begin{tabular}{|l|l|l|l|}
\hline No. & Instrument & Model & Company \\
\hline 1 & Deep-Freeze & JSPC-420C & Concord \\
\hline 2 & Blender & MX-GX1021 & Panasonic \\
\hline 3 & Balance & ALS220-4 & Kern \\
\hline 4 & Vortex & Gallenhamp & Spinmix \\
\hline 5 & Centrifuge & 5430R & Hamborg-Germany \\
\hline 6 & GC/MS & QP2010Plus & Shimadzu-Japan \\
\hline 7 & Polypropylene tubes & - & China \\
\hline 8 & Knife & - & China \\
\hline 9 & Glass gar & - & China \\
\hline
\end{tabular}

\section{Chemicals and solvents}

The chemicals and solvents brought from Sigma-Aldrich company (Germany) by OMA International office in Baghdad. All chemicals that are used described in the (Table 2) below.

Table (2) Chemicals and Solvents

\begin{tabular}{|l|l|l|l|l|}
\hline \multicolumn{1}{|c|}{ Chemicals } & $\begin{array}{l}\text { M.wt } \\
\text { g/mol }\end{array}$ & Chemical formula & $\begin{array}{l}\text { Density } \\
\text { g/mL }\end{array}$ & Company \\
\hline Acetonitrile & 41 & $\mathrm{C}_{2} \mathrm{H}_{3} \mathrm{~N}$ & 0.786 & Sigma-Aldrich \\
\hline Glacial Acetic acid & 60 & $\mathrm{C}_{2} \mathrm{H}_{4} \mathrm{O}_{2}$ & 1.049 & Sigma-Aldrich \\
\hline Anhydrous Magnesium Sulfate & 120.37 & $\mathrm{MgSo}_{4}$ & 2.66 & Sigma-Aldrich \\
\hline Anhydrous Sodium Acetate & 82.03 & $\mathrm{CH}_{3} \mathrm{COONa}$ & - & Sigma-Aldrich \\
\hline Primary Secondary Amine & 59 & $\mathrm{SiN}_{2} \mathrm{H}_{3}$ & - & Sigma-Aldrich \\
\hline Graphitized Carbon Black & 12 & $\mathrm{C}$ & 0.35 & Sigma-Aldrich \\
\hline
\end{tabular}

\section{GC/MS Optimal Condition Used for Samples Extracted by QuEChERS Method}

Helium was used as the carrier gas (mobile phase) at flow rate of $1.0 \mathrm{ml} / \mathrm{min}$. Separation were conducted using a Hp 5-Ms ultra inert $30 \mathrm{~m} * 0.25 \mathrm{~mm} * 0.25 \mu$ l column (stationary phase). The injection volume was $25 \mu \mathrm{l}$, the injector temperature was held at $\left(280^{\circ} \mathrm{C}\right)$. The program of GC/MS was set as follow: initial temperature started at $\left(70^{\circ} \mathrm{C}\right)$, held for $2 \mathrm{~min}$. Increased to $\left(150{ }^{\circ} \mathrm{C}\right)$ at $25^{\circ} \mathrm{C} / \mathrm{min}$, held for $1 \mathrm{~min}$. Finally, increased to $\left(280^{\circ} \mathrm{C}\right)$ at $8^{\circ} \mathrm{C} / \mathrm{min}$, held for $15 \mathrm{~min}[9]$.

\section{Determination of Pesticide Residues}

The determination of pesticide residues have been carried out by using mass spectroscopy coupled with gas chromatography [9].

\section{Sample Collection}

The targeted vegetables(tomato, cucumber, eggplant, and zucchini), have been collected from two sites, Al-Yusufiyah wholesaler market and Al-Rasheed wholesaler market. Table (3) shows the map of the two collection sites. The collection time were four months, (August, September, October, and November). The reason for chose those four months, are to cover the two kinds of planting for our targeted vegetables, exposed and green-house kinds of planting. Three times of collection were carried out per each month, starting of the month, middle of the month, and the end of the month. The reason for this kind of collection are to cover all the month targeted vegetables and to take comprehensive idea about pesticide residues in targeted vegetables. The total number of samples are (48) samples were distributed in targeted months as (Table 3) shows below.

Table (3) Sample Collection

\begin{tabular}{|l|l|l|l|l|}
\hline \multicolumn{1}{|c|}{ Sample } & \multicolumn{1}{c|}{ Month } & \multicolumn{1}{|c|}{ Date } & \multicolumn{1}{c|}{ Place of Planting } & \multicolumn{1}{c|}{ Place of Collection } \\
\hline Tomato & August & $5 / 8 / 2016$ & Karbala & Al-Rasheed wholesaler \\
\hline Tomato & August & $15 / 8 / 2016$ & Erbil & Al-Rasheed wholesaler \\
\hline Tomato & August & $30 / 8 / 2016$ & Erbil & Al-Rasheed wholesaler \\
\hline Tomato & September & $5 / 9 / 2016$ & Erbil & Al-Rasheed wholesaler \\
\hline Tomato & September & $15 / 9 / 2016$ & Pengawin & Al- Yusufiyah wholesaler \\
\hline Tomato & September & $29 / 9 / 2016$ & Pengawin & Al- Yusufiyah wholesaler \\
\hline Tomato & October & $5 / 10 / 2016$ & Rabia'a & Al- Yusufiyah wholesaler \\
\hline Tomato & October & $17 / 10 / 2016$ & Sulaimaniyah & Al-Rasheed wholesaler \\
\hline Tomato & October & $29 / 10 / 2016$ & Pengawin & Al-Rasheed wholesaler \\
\hline Tomato & November & $2 / 11 / 2016$ & Rabia'a & Al- Yusufiyah wholesaler \\
\hline Tomato & November & $16 / 11 / 2016$ & Karbala & Al-Rasheed wholesaler \\
\hline Tomato & November & $23 / 11 / 2016$ & Karbala & Al-Rasheed wholesaler \\
\hline Cucumber & August & $5 / 8 / 2016$ & Sulaimaniyah & Al-Rasheed wholesaler \\
\hline Cucumber & August & $15 / 8 / 2016$ & Sulaimaniyah & Al-Rasheed wholesaler \\
\hline Cucumber & August & $29 / 8 / 2016$ & Sulaimaniyah & Al-Rasheed wholesaler \\
\hline Cucumber & September & $5 / 9 / 2016$ & Al-Momniyah & Al- Yusufiyah wholesaler \\
\hline
\end{tabular}


Detection of Oxamyl and Imidacloprid Pesticide residues in Some Iraqi Vegetables

\begin{tabular}{|c|c|c|c|c|}
\hline Cucumber & September & $15 / 9 / 2016$ & Karbala & Al- Yusufiyah wholesaler \\
\hline Cucumber & September & $29 / 9 / 2016$ & Karbala & Al- Yusufiyah wholesaler \\
\hline Cucumber & October & $5 / 10 / 2016$ & Erbil & Al-Rasheed wholesaler \\
\hline Cucumber & October & $15 / 10 / 2016$ & Cragul & Al- Yusufiyah wholesaler \\
\hline Cucumber & October & $29 / 10 / 2016$ & Cragul & Al- Yusufiyah wholesaler \\
\hline Cucumber & November & $2 / 11 / 2016$ & Al- Harkawi & Al- Yusufiyah wholesaler \\
\hline Cucumber & November & $16 / 11 / 2016$ & Mahmudiyah & Al- Yusufiyah wholesaler \\
\hline Cucumber & November & $23 / 11 / 2016$ & Yusufiyah & Al-Rasheed wholesaler \\
\hline Eggplant & August & $5 / 8 / 2016$ & Yusufiyah & Al- Yusufiyah wholesaler \\
\hline Eggplant & August & $15 / 8 / 2016$ & Yusufiyah & Al-Rasheed wholesaler \\
\hline Eggplant & August & $24 / 8 / 2016$ & Yusufiyah & Al-Rasheed wholesaler \\
\hline Eggplant & September & $5 / 9 / 2016$ & Al-Momniyah & Al- Yusufiyah wholesaler \\
\hline Eggplant & September & $15 / 9 / 2016$ & Yusufiyah & Al- Yusufiyah wholesaler \\
\hline Eggplant & September & $29 / 9 / 2016$ & Essaouira & Al- Yusufiyah wholesaler \\
\hline Eggplant & October & $5 / 10 / 2016$ & Yusufiyah & Al- Yusufiyah wholesaler \\
\hline Eggplant & October & $15 / 10 / 2016$ & Yusufiyah & Al- Yusufiyah wholesaler \\
\hline Eggplant & October & $29 / 10 / 2016$ & Latifiyah & Al- Yusufiyah wholesaler \\
\hline Eggplant & November & $2 / 11 / 2016$ & Al-Saouira & Al- Yusufiyah wholesaler \\
\hline Eggplant & November & $16 / 11 / 2016$ & Al-Saouira & Al-Rasheed wholesaler \\
\hline Eggplant & November & $23 / 11 / 2016$ & Samarra & Al-Rasheed wholesaler \\
\hline Zucchini & August & $5 / 8 / 2016$ & Sulaimaniyah & Al-Rasheed wholesaler \\
\hline Zucchini & August & $15 / 8 / 2016$ & Sulaimaniyah & Al-Rasheed wholesaler \\
\hline Zucchini & August & $29 / 8 / 2016$ & Sulaimaniyah & Al-Rasheed wholesaler \\
\hline Zucchini & September & $9 / 9 / 2016$ & Erbil & Al-Rasheed wholesaler \\
\hline Zucchini & September & $18 / 9 / 2016$ & Erbil & Al-Rasheed wholesaler \\
\hline Zucchini & September & $29 / 9 / 2016$ & Erbil & Al-Rasheed wholesaler \\
\hline Zucchini & October & $5 / 10 / 2016$ & Yusufiyah & Al- Yusufiyah wholesaler \\
\hline Zucchini & October & $15 / 10 / 2016$ & Yusufiyah & Al- Yusufiyah wholesaler \\
\hline Zucchini & October & $29 / 10 / 2016$ & Latifiyah & Al- Yusufiyah wholesaler \\
\hline Zucchini & November & $2 / 11 / 2016$ & Al-Tahialiyah & Al- Yusufiyah wholesaler \\
\hline Zucchini & November & $16 / 11 / 2016$ & Yusufiyah & Al- Yusufiyah wholesaler \\
\hline Zucchini & November & $23 / 11 / 2016$ & Yusufiyah & Al-Rasheed wholesaler \\
\hline
\end{tabular}

\section{Sample Storage}

According to reference [10]. All samples had been stored in deep-freeze in $\left(-20^{\circ} \mathrm{C}\right)$. The reason of that step is to be sure that the concentration of pesticide residues, will not effect by metabolisms process of microorganisms decomposer when we are waiting our turn for analyzing our samples by GC/MS. The other purpose is to keep the concentration of pesticide residues, the same concentration when we reach the proper time for carryout treatment of pesticide residues experiment.

\section{Extraction Method}

The method that carried out for extract pesticide residues from targeted fruit tissue, is QuEChERS method. The reason behind choose this technique, is coming from the abbreviation name (QuEChERS). The name represent brief for those words, quick, easy, cheap, effective, rugged, and safe. The other reason representative with that, this technique is one of the innovation technique carried out for extraction pesticide residues from vegetables and fruit. According to reference [9]. The samples should be unwashed and with the peel intact. The samples were homogenized by using blender for time more than $1 \mathrm{~min}$ to gain homogenized mixture. After that, fifteen gram from homogenized mixture will be putted inside polypropylene centrifuge tube. Next, $15 \mathrm{ml}$ of stock solution consist of $(10 \mathrm{ml}$ glacial acetic acid $+1 \mathrm{~L}$ acetonitrile $)$, will be added to the tube. After that, $6 \mathrm{~g}$ of anhydrous magnesium sulfate $+1.5 \mathrm{~g}$ of anhydrous sodium acetate will be add to the mixture of the tube. Then the tube should be closed properly. Then samples should be shaken by using vortex for $1 \mathrm{~min}$, and centrifuge sample for $1 \mathrm{~min}$ at $1.6 \mathrm{RCF}$. According to [13], If your machine working with RPM unit, instead of RCF unit, we need to convert our unit. So we must apply the following equation for conversion process:

$\mathrm{RCF}=1.12 * \mathrm{R} *(\mathrm{RPM} / 1000) 2$

whereas:

$\mathrm{R}$ : the radius of rotation centrifuge head measured in millimeters.

So the equation will be:

$1.6=1.12 * 180 *(\mathrm{RPM} / 1000) 2$

So $\mathrm{RPM}=89.09$.

Then $2 \mathrm{ml}$ of supernatant was transferred to polypropylene centrifuge tube contain $100 \mathrm{mg}$ primary secondary amine $+300 \mathrm{mg}$ anhydrous magnesium sulfate. Next $50 \mathrm{mg}$ of graphitized carbon black was added to the tube. The tube was vortexed for 30 second and centrifuged again at 89.09 RPM for 1 min. After that, aliquot will be transferred to GC/MS vial. Now the analyte ready for GC/MS injection [9]. 
GC/MS Results

\section{Result And Discussion}

Samples were analyzed by using GC/MS instrument after extraction process had been done. (Table 4) show the results of GC/MS.

Table (4)

\begin{tabular}{|c|c|c|c|c|c|c|c|}
\hline $\begin{array}{l}\text { Sampl } \\
\text { e }\end{array}$ & Date & Compound & $\begin{array}{l}\text { Formul } \\
\text { a }\end{array}$ & $\begin{array}{l}\text { Rete } \\
\text { ntion } \\
\text { time }\end{array}$ & $\begin{array}{l}\text { Peak } \\
\text { area }\end{array}$ & $\begin{array}{l}\text { Peak } \\
\text { height }\end{array}$ & Relationship with pesticides \\
\hline \multirow[t]{4}{*}{$\begin{array}{l}\text { Tomat } \\
\mathrm{o}\end{array}$} & $5 / 8 / 2016$ & 2,3 butanediol & $\mathrm{C}_{4} \mathrm{H}_{10} \mathrm{O}_{2}$ & 2.312 & 475729 & $\begin{array}{l}28904 \\
2\end{array}$ & One of the components used in manufacture imidacloprid. \\
\hline & \multirow[t]{2}{*}{$\begin{array}{l}15 / 8 / 201 \\
6\end{array}$} & 2,3 butanediol & $\mathrm{C}_{4} \mathrm{H}_{10} \mathrm{O}_{2}$ & 2.028 & 5710981 & $\begin{array}{l}22665 \\
26\end{array}$ & One of the components used in manufacture imidacloprid. \\
\hline & & Acetamiprid & $\begin{array}{l}\mathrm{C}_{10} \mathrm{H}_{11} \mathrm{C} \\
1 \mathrm{~N}_{4}\end{array}$ & $\begin{array}{l}23.79 \\
1\end{array}$ & 645119 & $\begin{array}{l}23041 \\
7\end{array}$ & $\begin{array}{l}\text { Kind of neonicotinoid insecticide used widely in vegetables for } \\
\text { combatant pests. }\end{array}$ \\
\hline & $\begin{array}{l}30 / 8 / 201 \\
6\end{array}$ & 2,3-Butanediol & $\mathrm{C}_{4} \mathrm{H}_{10} \mathrm{O}_{2}$ & 3.496 & 617123 & $\begin{array}{l}41978 \\
0\end{array}$ & One of the components used in manufacture imidacloprid. \\
\hline \multirow[t]{10}{*}{$\begin{array}{l}\text { Tomat } \\
\text { o }\end{array}$} & \multirow[t]{10}{*}{$5 / 9 / 2016$} & $\begin{array}{l}\text { 3-Butenoic } \\
\text { acid, ethyl } \\
\text { ester }\end{array}$ & $\mathrm{C}_{6} \mathrm{H}_{10} \mathrm{O}_{2}$ & 4.098 & 27263 & 11950 & Kind of insecticides \\
\hline & & $\begin{array}{ll}\text { Allyl vinyl } \\
\text { ether }\end{array}$ & $\mathrm{C}_{5} \mathrm{H}_{8} \mathrm{O}$ & 4.098 & 27263 & 11950 & $\begin{array}{l}\text { Natural product produced by plants for protect them from oxamyl } \\
\text { toxicity under the stress of oxamyl. }\end{array}$ \\
\hline & & $\begin{array}{l}\text { t- } \\
\text { Butylethyliden } \\
\text { eamine }\end{array}$ & $\mathrm{C}_{6} \mathrm{H}_{13} \mathrm{~N}$ & 6.593 & 37510 & 17390 & $\begin{array}{l}\text { Adjuvant product add to oxamyl and imidacloprid pesticides for } \\
\text { improve the properties of delivering the pesticide from soil to plant, } \\
\text { it is also increase the activity of pesticides in killing pests. }\end{array}$ \\
\hline & & Shellsol 140 & $\mathrm{C}_{9} \mathrm{H}_{20}$ & 7.876 & 93175 & 50685 & $\begin{array}{l}\text { Compound belong to oxamyl and imidacloprid solvent, it is part } \\
\text { from the constituent of solvent composed of aromatic hydrocarbon. }\end{array}$ \\
\hline & & 1- hexene & $\mathrm{C}_{6} \mathrm{H}_{12}$ & $\begin{array}{l}10.50 \\
2\end{array}$ & 858744 & $\begin{array}{l}13019 \\
4\end{array}$ & $\begin{array}{l}\text { Natural product produced by plants under stress of imidacloprid } \\
\text { represent lignin emulsion, the emulsion of this product has ability to } \\
\text { control imidacloprid toxicity by combination with active ingredients } \\
\text { of pesticide. }\end{array}$ \\
\hline & & Heksan & $\mathrm{C}_{6} \mathrm{H}_{14}$ & $\begin{array}{l}12.67 \\
2\end{array}$ & 29150 & 18573 & $\begin{array}{l}\text { Kind of solvent used with imidacloprid pesticide, it has ability to } \\
\text { dilute imidacloprid as, Heksan }<0.1 \mathrm{~g} / \mathrm{L} \text { at } 20^{\circ} \mathrm{c}\end{array}$ \\
\hline & & $\begin{array}{l}\text { Diheptyl } \\
\text { phthalate }\end{array}$ & $\begin{array}{l}\mathrm{C}_{22} \mathrm{H}_{34} \mathrm{O} \\
4\end{array}$ & $\begin{array}{l}18.48 \\
7\end{array}$ & 48141 & 26345 & $\begin{array}{l}\text { Compound add to imidacloprid pesticide for reduce the degradation } \\
\text { of pesticide by oxidation, it is play important role in reduce the } \\
\text { ability of pesticide carbon for absorb oxygen. and that will increase } \\
\text { the activity of pesticide by increasing half-life of pesticide. }\end{array}$ \\
\hline & & $\begin{array}{l}\text { Octamethylene } \\
\text { glycol }\end{array}$ & $\mathrm{C}_{8} \mathrm{H}_{18} \mathrm{O}_{2}$ & $\begin{array}{l}20.69 \\
1\end{array}$ & 51541 & 20776 & $\begin{array}{l}\text { Compound add to imidacloprid pesticide for reducing the formation } \\
\text { of foam when farmers dilute the pesticide for reaching the proper } \\
\text { concentration for application, foam reduce the solubility of } \\
\text { pesticide and effect on pesticide activity in killing pests. }\end{array}$ \\
\hline & & $\begin{array}{l}\text { Nonyl } \\
\text { chloroacetate }\end{array}$ & $\begin{array}{l}\mathrm{C}_{11} \mathrm{H}_{21} \mathrm{C} \\
1 \mathrm{O}_{2}\end{array}$ & $\begin{array}{l}20.69 \\
1\end{array}$ & 51541 & 20776 & $\begin{array}{l}\text { Compound used in manufacturing 6-(5- chloropyridin-2-yl)-2-pent- } \\
\text { 2-ynyl-4,5-dihydropyridazin-3(2H)-one, the latest compound add to } \\
\text { imidacloprid for synergism purposes. }\end{array}$ \\
\hline & & Farnesol & $\mathrm{C}_{15} \mathrm{H}_{26} \mathrm{O}$ & $\begin{array}{l}28.19 \\
9\end{array}$ & 57195 & 18850 & $\begin{array}{l}\text { Compound add to imidacloprid pesticide for increase pesticide } \\
\text { activity in killing pests. }\end{array}$ \\
\hline \multirow[t]{12}{*}{$\begin{array}{l}\text { Tomat } \\
\text { o }\end{array}$} & \multirow[t]{5}{*}{$\begin{array}{l}15 / 9 / 201 \\
6\end{array}$} & $\begin{array}{l}\text { Di-tert- } \\
\text { butyldiazene }\end{array}$ & $\mathrm{C}_{8} \mathrm{H}_{18} \mathrm{~N}_{2}$ & 6.597 & 14371 & 6545 & $\begin{array}{l}\text { Kind of component belong to azithiram pesticide, this pesticide } \\
\text { belong to carbamate group of pesticides so it has the same mode of } \\
\text { action of oxamyl. }\end{array}$ \\
\hline & & 1-hexen & $\mathrm{C}_{6} \mathrm{H}_{12}$ & $\begin{array}{l}10.54 \\
9\end{array}$ & 518769 & 57043 & $\begin{array}{l}\text { Natural product produced by plants under stress of imidacloprid } \\
\text { represent lignin emulsion, the emulsion of this product has ability to } \\
\text { control imidacloprid toxicity by combination with active ingredients } \\
\text { of pesticide. }\end{array}$ \\
\hline & & $\begin{array}{l}\text { Tetrahydrofurf } \\
\text { uryl chloride }\end{array}$ & $\begin{array}{l}\mathrm{C}_{5} \mathrm{H}_{9} \mathrm{Cl} \\
\mathrm{O}\end{array}$ & $\begin{array}{l}15.33 \\
7\end{array}$ & 11548 & 6694 & $\begin{array}{l}\text { Compound used in production of clothianidin pesticide, the } \\
\text { pesticide is kind of neonicotinoid group of pesticide so it has the } \\
\text { same mode of action of imidacloprid }\end{array}$ \\
\hline & & Caprolactam & $\begin{array}{l}\mathrm{C}_{6} \mathrm{H}_{11} \mathrm{~N} \\
\mathrm{O}\end{array}$ & $\begin{array}{l}10.54 \\
9\end{array}$ & 518769 & 57043 & Additives add to oxamyl and imidacloprid pesticide \\
\hline & & $\begin{array}{l}\text { Hexadecanoic } \\
\text { acid }\end{array}$ & $\begin{array}{l}\mathrm{C}_{16} \mathrm{H}_{32} \mathrm{O} \\
2\end{array}$ & $\begin{array}{l}19.50 \\
0\end{array}$ & 356508 & 76682 & Compound produced when plant under stress of imidacloprid \\
\hline & \multirow[t]{7}{*}{$\begin{array}{l}29 / 9 / 201 \\
6\end{array}$} & Isobutanol & $\mathrm{C}_{4} \mathrm{H}_{10} \mathrm{O}$ & 2.025 & 22496 & 43911 & $\begin{array}{l}\text { Alcohols add to oxamyl and imidacloprid pesticides for better } \\
\text { distribution of pesticides inside plants. }\end{array}$ \\
\hline & & $\begin{array}{l}\text { 2,2-Dimethyl } \\
\text { pentane }\end{array}$ & $\mathrm{C}_{7} \mathrm{H}_{16}$ & 6.242 & 28416 & 18502 & $\begin{array}{l}\text { Compound produced by plants for formation of lignin-based matrix } \\
\text { micro-particles for control imidacloprid active ingredients by } \\
\text { formation of emulsion }\end{array}$ \\
\hline & & Caprolactam & $\begin{array}{l}\mathrm{C}_{6} \mathrm{H}_{11} \mathrm{~N} \\
\mathrm{O}\end{array}$ & 8.127 & 183619 & 25537 & Additives add to oxamyl and imidacloprid pesticide \\
\hline & & $\begin{array}{l}\text { Hexadecanoic } \\
\text { acid }\end{array}$ & $\mathrm{C}_{16} \mathrm{H}_{32} \mathrm{O}$ & $\begin{array}{l}14.06 \\
2\end{array}$ & 477118 & $\begin{array}{l}22215 \\
5\end{array}$ & Compound produced when plant under stress of imidacloprid \\
\hline & & $\begin{array}{l}\text { Dibutyl } \\
\text { phthalate }\end{array}$ & $\mathrm{C}_{16} \mathrm{H}_{22} \mathrm{O}$ & $\begin{array}{l}14.11 \\
7\end{array}$ & 41215 & 36105 & $\begin{array}{l}\text { Compound add to oxamyl and imidacloprid pesticides, it has grate } \\
\text { impact in preventing volatilization, crystallization, and precipitation } \\
\text { of active ingredients for both pesticides. }\end{array}$ \\
\hline & & Oleamide & $\begin{array}{l}\mathrm{C}_{18} \mathrm{H}_{35} \mathrm{~N} \\
\mathrm{O}\end{array}$ & $\begin{array}{l}15.59 \\
7\end{array}$ & 50502 & 20136 & $\begin{array}{l}\text { Compound has ability for make inhibition for acetylcholinesterase } \\
\text { enzyme, so it is add with the mixture of oxamyl pesticide for } \\
\text { fortification the impact of pesticide. }\end{array}$ \\
\hline & & $\begin{array}{l}\text { 3- } \\
\text { Heptadecanol }\end{array}$ & $\mathrm{C}_{17} \mathrm{H}_{36} \mathrm{O}$ & $\begin{array}{l}16.72 \\
4\end{array}$ & 986302 & $\begin{array}{l}26889 \\
4\end{array}$ & $\begin{array}{l}\text { Compound add to oxamyl and imidacloprid pesticides, it is } \\
\text { represent fatty alcohols that is able to control drift of oxamyl and } \\
\text { imidacloprid after application on soil. }\end{array}$ \\
\hline Tomat & $5 / 10 / 201$ & Hexadecanoic & $\mathrm{C}_{16} \mathrm{H}_{32} \mathrm{O}$ & 20.44 & 2114454 & 90536 & Compound produced when plant under stress of imidacloprid \\
\hline
\end{tabular}


Detection of Oxamyl and Imidacloprid Pesticide residues in Some Iraqi Vegetables

\begin{tabular}{|c|c|c|c|c|c|c|c|}
\hline \multirow[t]{5}{*}{ o } & \multirow[t]{5}{*}{6} & acid & 2 & 9 & & 7 & \\
\hline & & $\begin{array}{l}\text { Tridecanoic } \\
\text { acid }\end{array}$ & $\mathrm{C}_{13} \mathrm{H}_{26} \mathrm{O}$ & $\begin{array}{l}20.44 \\
9\end{array}$ & 2114454 & $\begin{array}{l}90536 \\
7\end{array}$ & $\begin{array}{l}\text { Additives add to oxamyl and imidacloprid pesticides for increase } \\
\text { their control on pest }\end{array}$ \\
\hline & & $\begin{array}{l}\text { E-9- } \\
\text { Tetradecenal }\end{array}$ & $\begin{array}{l}\mathrm{C} 14 \mathrm{H} 26 \\
\mathrm{O}\end{array}$ & $\begin{array}{l}25.21 \\
7\end{array}$ & 411509 & $\begin{array}{l}19027 \\
6\end{array}$ & $\begin{array}{l}\text { Attractants add to oxamyl and imidacloprid pesticides for } \\
\text { conservation environment, increase pesticide activity, and alter the } \\
\text { pest behaviors. }\end{array}$ \\
\hline & & $\begin{array}{l}2,13- \\
\text { octadecadien- } \\
1-\mathrm{ol}\end{array}$ & $\mathrm{C}_{18} \mathrm{H}_{34} \mathrm{O}$ & $\begin{array}{l}25.21 \\
7\end{array}$ & 411509 & $\begin{array}{l}19027 \\
6\end{array}$ & $\begin{array}{l}\text { This compound represent kind of insect pheromones add to oxamyl } \\
\text { and imidacloprid pesticides as additives play important role in as } \\
\text { insect attractive and alter the pest behaviors, it fortified the } \\
\text { pesticides performance. }\end{array}$ \\
\hline & & $\begin{array}{l}\text { E-11- } \\
\text { Hexadecenal }\end{array}$ & $\mathrm{C}_{16} \mathrm{H}_{30} \mathrm{O}$ & $\begin{array}{l}25.21 \\
7\end{array}$ & 411509 & $\begin{array}{l}19027 \\
6\end{array}$ & $\begin{array}{l}\text { Attractants add to oxamyl and imidacloprid pesticides for } \\
\text { conservation environment, increase pesticide activity, and alter the } \\
\text { pest behaviors. }\end{array}$ \\
\hline \multirow[t]{5}{*}{$\begin{array}{l}\text { Tomat } \\
\text { o }\end{array}$} & \multirow[t]{5}{*}{$\begin{array}{l}17 / 10 / 20 \\
16\end{array}$} & $\begin{array}{l}\text { Hexadecanoic } \\
\text { acid }\end{array}$ & $\begin{array}{l}\mathrm{C}_{16} \mathrm{H}_{32} \mathrm{O} \\
2\end{array}$ & $\begin{array}{l}15.88 \\
3\end{array}$ & 207277 & 57104 & $\begin{array}{l}\text { Compound produced by plants when they are under stress of } \\
\text { imidacloprid. }\end{array}$ \\
\hline & & $\begin{array}{l}\text { Tridecanoic } \\
\text { acid }\end{array}$ & $\begin{array}{l}\mathrm{C}_{13} \mathrm{H}_{26} \mathrm{O} \\
2\end{array}$ & $\begin{array}{l}15.88 \\
3\end{array}$ & 207277 & 57104 & $\begin{array}{l}\text { Additives add to oxamyl and imidacloprid pesticides for increase } \\
\text { their control on pest }\end{array}$ \\
\hline & & $\begin{array}{l}\text { E-9- } \\
\text { Tetradecenal }\end{array}$ & $\mathrm{C}_{14} \mathrm{H}_{26} \mathrm{O}$ & $\begin{array}{l}25.21 \\
6\end{array}$ & 1349473 & $\begin{array}{l}50923 \\
7\end{array}$ & $\begin{array}{l}\text { Attractant substance add to oxamyl and imidacloprid pesticides for } \\
\text { conservation environment and increase the efficiency of pesticide } \\
\text { by altering the behaviors of pest insect. }\end{array}$ \\
\hline & & $\begin{array}{l}2,13 \\
\text { octadecadien- } \\
1-\text { ol }\end{array}$ & $\mathrm{C}_{18} \mathrm{H}_{34} \mathrm{O}$ & $\begin{array}{l}27.41 \\
0\end{array}$ & 472691 & $\begin{array}{l}14603 \\
9\end{array}$ & $\begin{array}{l}\text { This compound represent kind of insect pheromones add to oxamyl } \\
\text { and imidacloprid pesticides as additives play important role in as } \\
\text { insect attractive and alter the pest behaviors, it fortified the } \\
\text { pesticides performance. }\end{array}$ \\
\hline & & 7-Hexadecenal & $\mathrm{C}_{16} \mathrm{H}_{30} \mathrm{O}$ & $\begin{array}{l}27.41 \\
0\end{array}$ & 472691 & $\begin{array}{l}14603 \\
9\end{array}$ & $\begin{array}{l}\text { Attractant substance add to oxamyl and imidacloprid pesticides for } \\
\text { conservation environment and increase the efficiency of pesticide } \\
\text { by altering the behaviors of pest insect. }\end{array}$ \\
\hline \multirow[t]{5}{*}{$\begin{array}{l}\text { Tomat } \\
\mathrm{o}\end{array}$} & \multirow[t]{5}{*}{$\begin{array}{l}29 / 10 / 20 \\
16\end{array}$} & $\begin{array}{l}\text { Hexadecanoic } \\
\text { acid }\end{array}$ & $\begin{array}{l}\mathrm{C}_{16} \mathrm{H}_{32} \mathrm{O} \\
2\end{array}$ & $\begin{array}{l}15.92 \\
6\end{array}$ & 673812 & $\begin{array}{l}31623 \\
3\end{array}$ & $\begin{array}{l}\text { Compound produced by plants when they are under stress of } \\
\text { imidacloprid. }\end{array}$ \\
\hline & & $\begin{array}{l}\text { Tridecanoic } \\
\text { acid }\end{array}$ & $\begin{array}{l}\mathrm{C}_{13} \mathrm{H}_{26} \mathrm{O} \\
2\end{array}$ & $\begin{array}{l}15.92 \\
6\end{array}$ & 673812 & $\begin{array}{l}31623 \\
3\end{array}$ & $\begin{array}{l}\text { Additives add to oxamyl and imidacloprid pesticides for increase } \\
\text { their control on pest }\end{array}$ \\
\hline & & $\begin{array}{l}\text { E-9- } \\
\text { Tetradecenal }\end{array}$ & $\mathrm{C}_{14} \mathrm{H}_{26} \mathrm{O}$ & $\begin{array}{l}25.25 \\
8\end{array}$ & 3768786 & $\begin{array}{l}16171 \\
32\end{array}$ & $\begin{array}{l}\text { Attractant substance add to oxamyl and imidacloprid pesticides for } \\
\text { conservation environment and increase the efficiency of pesticide } \\
\text { by altering the behaviors of pest insect. }\end{array}$ \\
\hline & & $\begin{array}{l}\text { E-11- } \\
\text { hexadecenal }\end{array}$ & $\mathrm{C}_{16} \mathrm{H}_{30} \mathrm{O}$ & $\begin{array}{l}27.47 \\
2\end{array}$ & 1475434 & $\begin{array}{l}36885 \\
6\end{array}$ & $\begin{array}{l}\text { Attractant substance add to oxamyl and imidacloprid pesticides for } \\
\text { conservation environment and increase the efficiency of pesticide } \\
\text { by altering the behaviors of pest insect. }\end{array}$ \\
\hline & & $\begin{array}{l}\text { Diisopropyl } \\
\text { sulfite }\end{array}$ & $\begin{array}{l}\mathrm{C}_{6} \mathrm{H}_{14} \mathrm{O}_{3} \\
\mathrm{~S}\end{array}$ & 2.423 & $\begin{array}{l}11012482 \\
3\end{array}$ & $\begin{array}{l}19165 \\
230\end{array}$ & $\begin{array}{l}\text { Compound add to oxamyl and imidacloprid pesticides for formation } \\
\text { emulsion that is help in more dispersion of pesticides. }\end{array}$ \\
\hline \multirow[t]{3}{*}{$\begin{array}{l}\text { Tomat } \\
\mathrm{o}\end{array}$} & $\begin{array}{l}2 / 11 / 201 \\
6\end{array}$ & - & - & - & - & - & $\begin{array}{l}\text { There is no compounds have relationship with pesticides or } \\
\text { pesticides themselves. }\end{array}$ \\
\hline & $\begin{array}{l}16 / 11 / 20 \\
16\end{array}$ & - & - & - & - & - & $\begin{array}{l}\text { There is no compounds have relationship with pesticides or } \\
\text { pesticides themselves. }\end{array}$ \\
\hline & $\begin{array}{l}23 / 11 / 20 \\
16\end{array}$ & - & - & - & - & - & $\begin{array}{l}\text { There is no compounds have relationship with pesticides or } \\
\text { pesticides themselves. }\end{array}$ \\
\hline \multirow[t]{3}{*}{$\begin{array}{l}\text { Eggpla } \\
\text { nt }\end{array}$} & $5 / 8 / 2016$ & 2,3-Butanediol & $\mathrm{C}_{4} \mathrm{H}_{10} \mathrm{O}_{2}$ & 2.200 & 244549 & $\begin{array}{l}18720 \\
8\end{array}$ & One of the components used in manufacture imidacloprid. \\
\hline & $\begin{array}{l}15 / 8 / 201 \\
6\end{array}$ & 2,3-Butanediol & $\mathrm{C}_{4} \mathrm{H}_{10} \mathrm{O}_{2}$ & 2.208 & 301285 & $\begin{array}{l}23303 \\
6 \\
\end{array}$ & One of the components used in manufacture imidacloprid. \\
\hline & $\begin{array}{l}24 / 8 / 201 \\
6\end{array}$ & - & - & - & - & - & $\begin{array}{l}\text { There is no compounds have relationship with pesticides or } \\
\text { pesticides themselves. }\end{array}$ \\
\hline \multirow[t]{5}{*}{$\begin{array}{l}\text { Eggpla } \\
\text { nt }\end{array}$} & \multirow[t]{5}{*}{$\begin{array}{l}5 / 9 / 2016 \\
5 / 9 / 2016\end{array}$} & $\begin{array}{l}\text { Diheptyl } \\
\text { phthalate }\end{array}$ & $\begin{array}{l}\mathrm{C}_{22} \mathrm{H}_{34} \mathrm{O} \\
4\end{array}$ & $\begin{array}{l}17.47 \\
3\end{array}$ & 24686 & 11547 & $\begin{array}{l}\text { Compound add to imidacloprid pesticide for reduce pesticide } \\
\text { oxidation, so this will play important role in reduce pesticide } \\
\text { degradation, the compound play important role in reduce amount of } \\
\text { oxygen that are absorbed by pesticide carbon that is found in } \\
\text { pesticide structure. }\end{array}$ \\
\hline & & $\begin{array}{l}\text { Hexadecanoic } \\
\text { acid }\end{array}$ & $\begin{array}{l}\mathrm{C}_{16} \mathrm{H}_{32} \mathrm{O} \\
2\end{array}$ & $\begin{array}{l}18.43 \\
6\end{array}$ & 956470 & $\begin{array}{l}25476 \\
8\end{array}$ & $\begin{array}{l}\text { Compound produced by plants when they are under stress of } \\
\text { imidacloprid. }\end{array}$ \\
\hline & & Oleamide & $\begin{array}{l}\mathrm{C}_{18} \mathrm{H}_{35} \mathrm{~N} \\
\mathrm{O}\end{array}$ & $\begin{array}{l}22.32 \\
0\end{array}$ & 697154 & $\begin{array}{l}14664 \\
3\end{array}$ & $\begin{array}{l}\text { Compound add to oxamyl pesticide for improve it's effect as acetyl } \\
\text { cholinesterase enzyme inhibitor, it is consider as amide of oleic acid } \\
\text { and classified as long chain alcohols, it play important role in block } \\
\text { connexin molecules in acetyl cholinesterase enzyme. }\end{array}$ \\
\hline & & $\begin{array}{l}3- \\
\text { Heptadecanol } \\
\end{array}$ & $\mathrm{C}_{17} \mathrm{H}_{36} \mathrm{O}$ & $\begin{array}{l}22.32 \\
0\end{array}$ & 697154 & $\begin{array}{l}14664 \\
3 \\
\end{array}$ & $\begin{array}{l}\text { Compound add to imidacloprid and oxamyl pesticide as drift } \\
\text { control agent, it represent kind of fatty alcohol. }\end{array}$ \\
\hline & & $\begin{array}{l}\text { 2,4-Dimethyl } \\
\text { pentane }\end{array}$ & $\mathrm{C}_{7} \mathrm{H}_{16}$ & 7.084 & 28219 & 15128 & $\begin{array}{l}\text { Compound produced by plants for formation lignin-based matrix } \\
\text { micro particles, the latest compound play important role in control } \\
\text { release the active ingredients of pesticides and imidacloprid, is one } \\
\text { of them. }\end{array}$ \\
\hline \multirow[t]{5}{*}{$\begin{array}{l}\text { Eggpla } \\
\text { nt }\end{array}$} & \multirow[t]{5}{*}{$\begin{array}{l}15 / 9 / 201 \\
6\end{array}$} & 1-Hexene & $\mathrm{C}_{6} \mathrm{H}_{12}$ & 9.603 & 336969 & 42694 & $\begin{array}{l}\text { Natural product produced by plants under stress of imidacloprid } \\
\text { represent lignin emulsion, the emulsion of this product has ability to } \\
\text { control imidacloprid toxicity by combination with active ingredients } \\
\text { of pesticide. }\end{array}$ \\
\hline & & Caprolactam & $\begin{array}{l}\mathrm{C}_{6} \mathrm{H}_{11} \mathrm{~N} \\
\mathrm{O}\end{array}$ & 9.603 & 336969 & 42694 & Additives add to oxamyl and imidacloprid pesticide \\
\hline & & $\begin{array}{l}\text { Hexadecanoic } \\
\text { acid }\end{array}$ & $\begin{array}{l}\mathrm{C}_{16} \mathrm{H}_{32} \mathrm{O} \\
2\end{array}$ & $\begin{array}{l}18.43 \\
9\end{array}$ & 1242773 & $\begin{array}{l}27761 \\
6\end{array}$ & $\begin{array}{l}\text { Compound produced by plants when they are under stress of } \\
\text { imidacloprid. }\end{array}$ \\
\hline & & Dodecanal & $\mathrm{C}_{12} \mathrm{H}_{24} \mathrm{O}$ & 2.063 & 2657962 & $\begin{array}{l}70876 \\
7 \\
\end{array}$ & $\begin{array}{l}\text { Kind of insect pheromone add to oxamyl and imidacloprid for } \\
\text { attract the insect to pesticide compounds for more killing impact. }\end{array}$ \\
\hline & & $\begin{array}{l}\text { Dimethyl } \\
\text { formamide }\end{array}$ & $\mathrm{C}_{3} \mathrm{H}_{7} \mathrm{NO}$ & 2.550 & 148967 & 39036 & Kind of solvents used in preparation oxamyl pesticide. \\
\hline Eggpla & $29 / 9 / 201$ & Shellsol 140 & $\mathrm{C}_{9} \mathrm{H}_{20}$ & 7.083 & 81917 & 38656 & Compound belong to oxamyl and imidacloprid solvent, it is part \\
\hline
\end{tabular}


Detection of Oxamyl and Imidacloprid Pesticide residues in Some Iraqi Vegetables

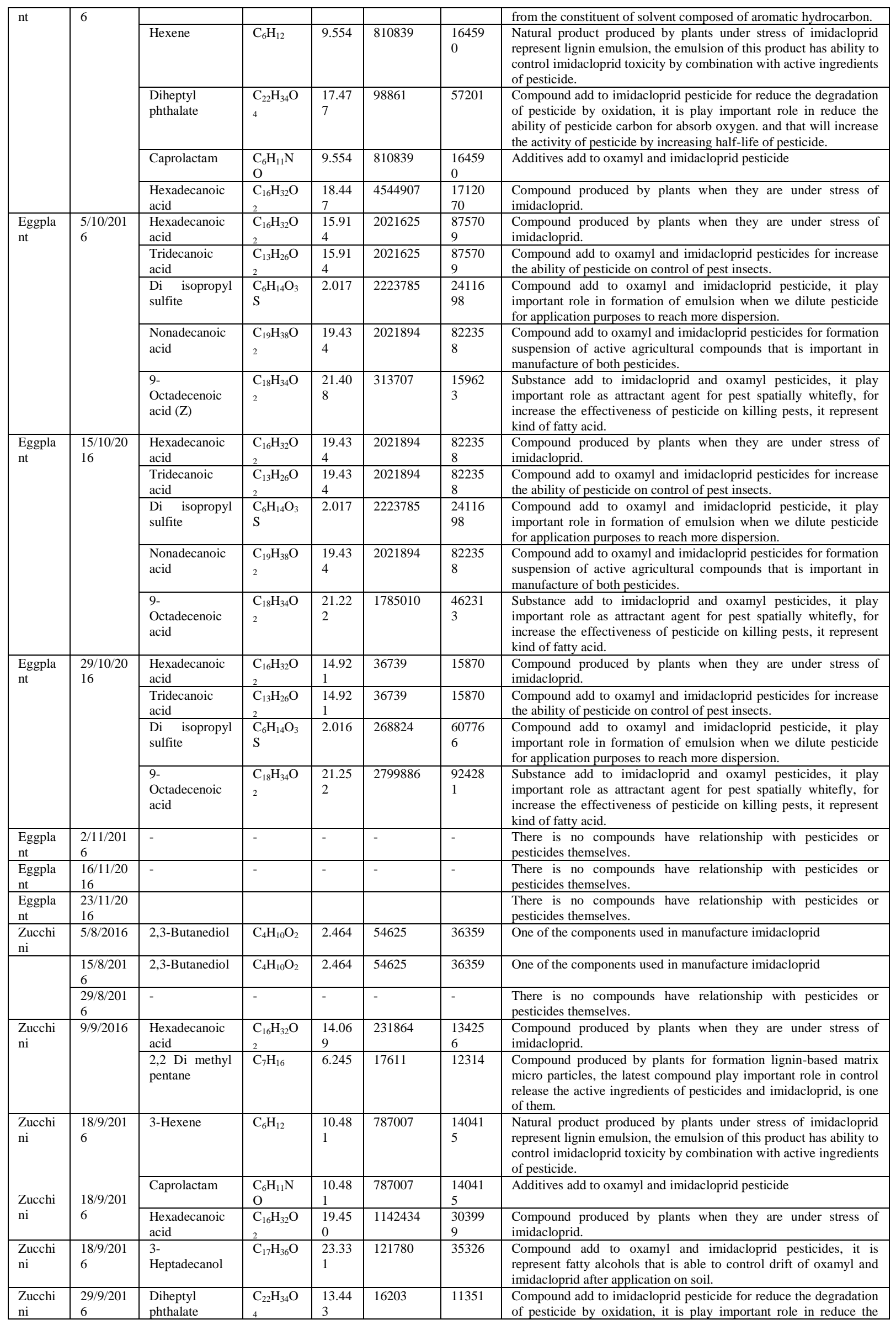


Detection of Oxamyl and Imidacloprid Pesticide residues in Some Iraqi Vegetables

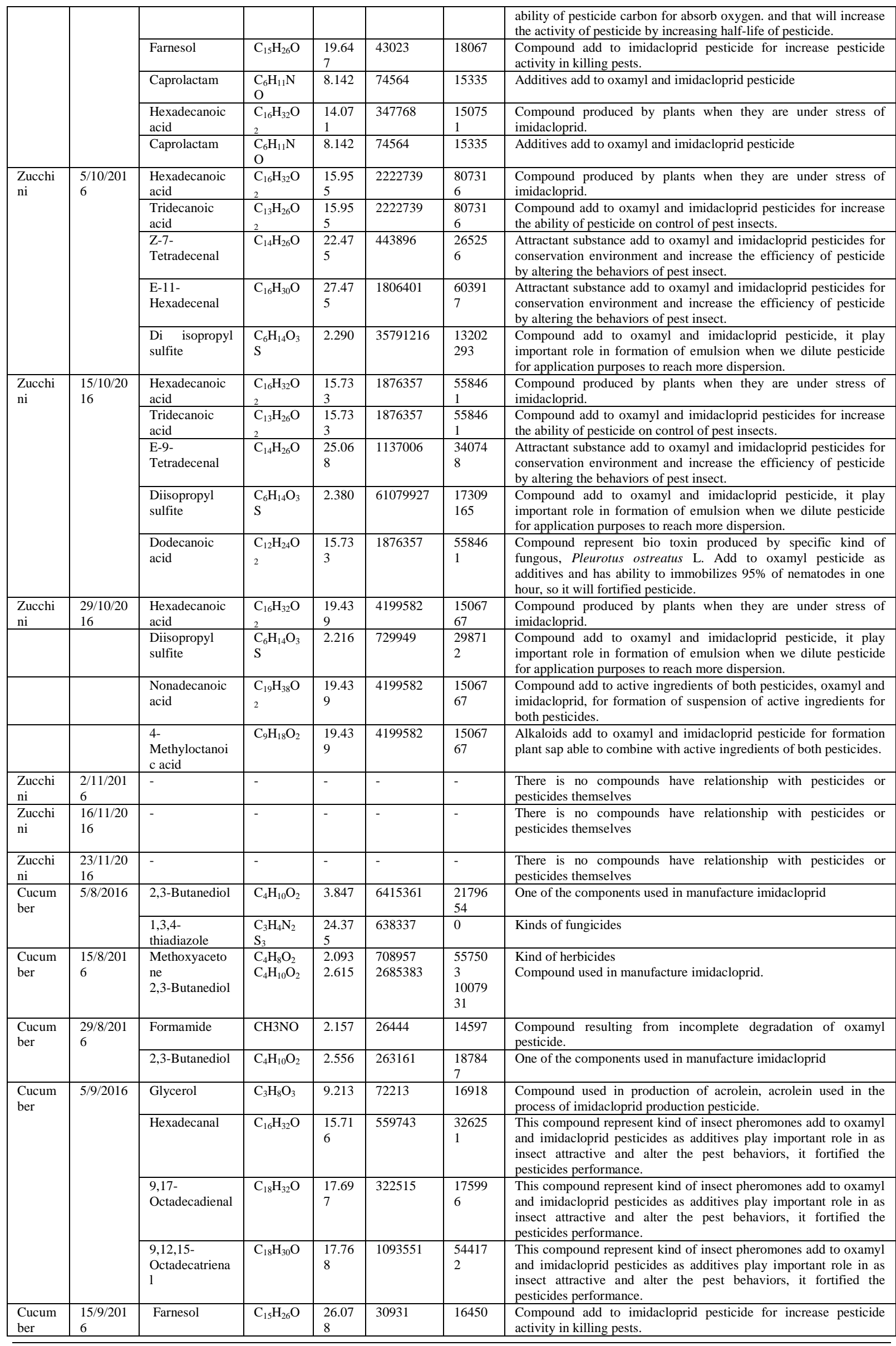


Detection of Oxamyl and Imidacloprid Pesticide residues in Some Iraqi Vegetables

\begin{tabular}{|c|c|c|c|c|c|c|c|}
\hline & & $\begin{array}{l}9,12,15- \\
\text { Octadecatriena } \\
1\end{array}$ & $\mathrm{C}_{18} \mathrm{H}_{30} \mathrm{O}$ & $\begin{array}{l}17.80 \\
3\end{array}$ & 113821 & 27970 & $\begin{array}{l}\text { This compound represent kind of insect pheromones add to oxamyl } \\
\text { and imidacloprid pesticides as additives play important role in as } \\
\text { insect attractive and alter the pest behaviors, it fortified the } \\
\text { pesticides performance. }\end{array}$ \\
\hline \multirow[t]{3}{*}{$\begin{array}{l}\text { Cucum } \\
\text { ber }\end{array}$} & \multirow[t]{3}{*}{$\begin{array}{l}15 / 9 / 201 \\
6\end{array}$} & Isovaleric acid & $\mathrm{C}_{5} \mathrm{H}_{10} \mathrm{O}_{2}$ & $\begin{array}{l}11.02 \\
1\end{array}$ & 8014 & 5417 & $\begin{array}{l}\text { Compound produced by plants when they are under stress of } \\
\text { oxamyl. }\end{array}$ \\
\hline & & $\begin{array}{l}\text { 2-Methylbutyl } \\
\text { butyrate }\end{array}$ & $\mathrm{C}_{9} \mathrm{H}_{18} \mathrm{O}_{2}$ & $\begin{array}{l}15.75 \\
7 \\
\end{array}$ & 56410 & 18399 & Compound add to oxamyl pesticide as attractance. \\
\hline & & $\begin{array}{l}\text { 1- } \\
\text { Cyclohexyleth } \\
\text { anamine }\end{array}$ & $\mathrm{C}_{8} \mathrm{H}_{17} \mathrm{~N}$ & $\begin{array}{l}20.31 \\
5\end{array}$ & 64220 & 11120 & $\begin{array}{l}\text { Compound add with oxamyl and imidacloprid pesticides as control } \\
\text { agent for agricultural pest. }\end{array}$ \\
\hline \multirow[t]{5}{*}{$\begin{array}{l}\text { Cucum } \\
\text { ber }\end{array}$} & \multirow[t]{5}{*}{$\begin{array}{l}29 / 9 / 201 \\
6\end{array}$} & Shellsol 140 & $\mathrm{C}_{9} \mathrm{H}_{20}$ & 7.892 & 88638 & 44979 & $\begin{array}{l}\text { Compound belong to oxamyl and imidacloprid solvent, it is part } \\
\text { from the constituent of solvent composed of aromatic hydrocarbon. }\end{array}$ \\
\hline & & 3-Hexene & $\mathrm{C}_{6} \mathrm{H}_{12}$ & $\begin{array}{l}10.50 \\
2\end{array}$ & 800980 & $\begin{array}{l}12208 \\
1\end{array}$ & $\begin{array}{l}\text { Natural product produced by plants under stress of imidacloprid } \\
\text { represent lignin emulsion, the emulsion of this product has ability to } \\
\text { control imidacloprid toxicity by combination with active ingredients } \\
\text { of pesticide. }\end{array}$ \\
\hline & & Farnesol & $\mathrm{C}_{15} \mathrm{H}_{26} \mathrm{O}$ & $\begin{array}{l}28.21 \\
2\end{array}$ & 92363 & 26314 & $\begin{array}{l}\text { Compound add to imidacloprid pesticide for increase pesticide } \\
\text { activity in killing pests. }\end{array}$ \\
\hline & & Caprolactam & $\begin{array}{l}\mathrm{C}_{6} \mathrm{H}_{11} \mathrm{~N} \\
\mathrm{O}\end{array}$ & $\begin{array}{l}10.50 \\
2\end{array}$ & 800980 & $\begin{array}{l}12208 \\
1\end{array}$ & Additives add to oxamyl and imidacloprid pesticide \\
\hline & & $\begin{array}{l}\text { 2,3- } \\
\text { Dimethylpenta } \\
\text { ne }\end{array}$ & $\mathrm{C}_{7} \mathrm{H}_{16}$ & 7.892 & 88638 & 44979 & $\begin{array}{l}\text { Compound produced by plants for formation lignin-based matrix } \\
\text { micro particles, the latest compound play important role in control } \\
\text { release the active ingredients of pesticides and imidacloprid, is one } \\
\text { of them. }\end{array}$ \\
\hline \multirow[t]{4}{*}{$\begin{array}{l}\text { Cucum } \\
\text { ber }\end{array}$} & \multirow[t]{4}{*}{$\begin{array}{l}5 / 10 / 201 \\
6\end{array}$} & $\begin{array}{l}\text { Hexadecanoic } \\
\text { acid }\end{array}$ & $\begin{array}{l}\mathrm{C}_{16} \mathrm{H}_{32} \mathrm{O} \\
2\end{array}$ & $\begin{array}{l}19.42 \\
4\end{array}$ & 700072 & $\begin{array}{l}32055 \\
8\end{array}$ & $\begin{array}{l}\text { Compound produced by plants when they are under stress of } \\
\text { imidacloprid. }\end{array}$ \\
\hline & & $\begin{array}{l}\text { Tridecanoic } \\
\text { acid }\end{array}$ & $\mathrm{C}_{13} \mathrm{H}_{26} \mathrm{O}$ & $\begin{array}{l}19.42 \\
4\end{array}$ & 700072 & $\begin{array}{l}32055 \\
8\end{array}$ & $\begin{array}{l}\text { Compound add to oxamyl and imidacloprid pesticides for increase } \\
\text { the ability of pesticide on control of pest insects. }\end{array}$ \\
\hline & & $\begin{array}{l}\text { Diisopropyl } \\
\text { sulfite }\end{array}$ & $\begin{array}{l}\mathrm{C}_{6} \mathrm{H}_{14} \mathrm{O}_{3} \\
\mathrm{~S}\end{array}$ & 2.017 & 1495985 & $\begin{array}{l}17269 \\
14\end{array}$ & $\begin{array}{l}\text { Compound add to oxamyl and imidacloprid pesticide, it play } \\
\text { important role in formation of emulsion when we dilute pesticide } \\
\text { for application purposes to reach more dispersion. }\end{array}$ \\
\hline & & $\begin{array}{l}9,11- \\
\text { Dodecadien-1- } \\
\text { ol }\end{array}$ & $\mathrm{C}_{12} \mathrm{H}_{22} \mathrm{O}$ & $\begin{array}{l}18.67 \\
5\end{array}$ & 28065 & 16930 & $\begin{array}{l}\text { Additive add to oxamyl and imidacloprid pesticides active } \\
\text { ingredients, it make synergism with oxamyl and imidacloprid } \\
\text { pesticides. }\end{array}$ \\
\hline \multirow[t]{5}{*}{$\begin{array}{l}\text { Cucum } \\
\text { ber }\end{array}$} & \multirow[t]{5}{*}{$\begin{array}{l}15 / 10 / 20 \\
16\end{array}$} & $\begin{array}{l}\text { Hexadecanoic } \\
\text { acid }\end{array}$ & $\begin{array}{l}\mathrm{C}_{16} \mathrm{H}_{32} \mathrm{O} \\
2\end{array}$ & $\begin{array}{l}15.91 \\
1\end{array}$ & 1421531 & $\begin{array}{l}60089 \\
1\end{array}$ & $\begin{array}{l}\text { Compound produced by plants when they are under stress of } \\
\text { imidacloprid. }\end{array}$ \\
\hline & & $\begin{array}{l}\text { Tridecanoic } \\
\text { acid }\end{array}$ & $\begin{array}{l}\mathrm{C}_{13} \mathrm{H}_{26} \mathrm{O} \\
2\end{array}$ & $\begin{array}{l}15.91 \\
1\end{array}$ & 1421531 & $\begin{array}{l}60089 \\
1 \\
\end{array}$ & $\begin{array}{l}\text { Compound add to oxamyl and imidacloprid pesticides for increase } \\
\text { the ability of pesticide on control of pest insects. }\end{array}$ \\
\hline & & $\begin{array}{l}\text { Dodecanoic } \\
\text { acid }\end{array}$ & $\mathrm{C}_{12} \mathrm{H}_{24} \mathrm{O}$ & $\begin{array}{l}15.91 \\
1\end{array}$ & 1421531 & $\begin{array}{l}60089 \\
1\end{array}$ & $\begin{array}{l}\text { Compound represent bio toxin produced by specific kind of } \\
\text { fungous, Pleurotus ostreatus L. Add to oxamyl pesticide as } \\
\text { additives and has ability to immobilizes } 95 \% \text { of nematodes in one } \\
\text { hour, so it will fortified pesticide. }\end{array}$ \\
\hline & & Decanoic acid & $\begin{array}{l}\mathrm{C}_{10} \mathrm{H}_{20} \mathrm{O} \\
2\end{array}$ & $\begin{array}{l}15.91 \\
1\end{array}$ & 1421531 & $\begin{array}{l}60089 \\
1\end{array}$ & $\begin{array}{l}\text { Compound represent bio toxin produced by specific kind of } \\
\text { fungous, Pleurotus ostreatus L. Add to oxamyl pesticide as } \\
\text { additives and has ability to immobilizes } 95 \% \text { of nematodes in one } \\
\text { hour, so it will fortified pesticide. }\end{array}$ \\
\hline & & Undecanal & $\mathrm{C}_{11} \mathrm{H}_{22} \mathrm{O}$ & $\begin{array}{l}17.71 \\
5\end{array}$ & 531133 & $\begin{array}{l}28714 \\
2\end{array}$ & $\begin{array}{l}\text { Synthetic fragrances add to imidacloprid and oxamyl pesticide, it } \\
\text { increased the foliar penetration of active ingredients or create } \\
\text { formulation of bait that increase the ability of pesticides on killing } \\
\text { pests. }\end{array}$ \\
\hline $\begin{array}{l}\text { Cucum } \\
\text { ber }\end{array}$ & $\begin{array}{l}29 / 10 / 20 \\
16\end{array}$ & $\begin{array}{l}\text { Hexadecanoic } \\
\text { acid }\end{array}$ & $\begin{array}{l}\mathrm{C}_{16} \mathrm{H}_{32} \mathrm{O} \\
2\end{array}$ & $\begin{array}{l}15.91 \\
3\end{array}$ & 1060373 & $\begin{array}{l}50295 \\
9 \\
\end{array}$ & $\begin{array}{l}\text { Compound produced by plants when they are under stress of } \\
\text { imidacloprid. }\end{array}$ \\
\hline \multirow[t]{4}{*}{$\begin{array}{l}\text { Cucum } \\
\text { ber }\end{array}$} & \multirow[t]{4}{*}{$\begin{array}{l}29 / 10 / 20 \\
16\end{array}$} & $\begin{array}{l}\text { Tridecanoic } \\
\text { acid }\end{array}$ & $\begin{array}{l}\mathrm{C}_{13} \mathrm{H}_{26} \mathrm{O} \\
2\end{array}$ & $\begin{array}{l}15.91 \\
3\end{array}$ & 1060373 & $\begin{array}{l}50295 \\
9 \\
\end{array}$ & $\begin{array}{l}\text { Compound add to oxamyl and imidacloprid pesticides for increase } \\
\text { the ability of pesticide on control of pest insects. }\end{array}$ \\
\hline & & $\begin{array}{l}\text { E-9- } \\
\text { Tetradecenal }\end{array}$ & $\mathrm{C}_{14} \mathrm{H}_{26} \mathrm{O}$ & $\begin{array}{l}25.23 \\
6\end{array}$ & 3062858 & $\begin{array}{l}15186 \\
93\end{array}$ & $\begin{array}{l}\text { Attractant substance add to oxamyl and imidacloprid pesticides for } \\
\text { conservation environment and increase the efficiency of pesticide } \\
\text { by altering the behaviors of pest insect. }\end{array}$ \\
\hline & & $\begin{array}{l}\text { Diisopropyl } \\
\text { sulfite }\end{array}$ & $\begin{array}{l}\mathrm{C}_{6} \mathrm{H}_{14} \mathrm{O}_{3} \\
\mathrm{~S}\end{array}$ & 2.017 & 13855718 & $\begin{array}{l}14225 \\
602\end{array}$ & $\begin{array}{l}\text { Compound add to oxamyl and imidacloprid pesticide, it play } \\
\text { important role in formation of emulsion when we dilute pesticide } \\
\text { for application purposes to reach more dispersion. }\end{array}$ \\
\hline & & Decanoic acid & $\begin{array}{l}\mathrm{C}_{10} \mathrm{H}_{20} \mathrm{O} \\
2\end{array}$ & $\begin{array}{l}15.91 \\
3\end{array}$ & 1060373 & $\begin{array}{l}50295 \\
9\end{array}$ & $\begin{array}{l}\text { Compound represent bio toxin produced by specific kind of } \\
\text { fungous, Pleurotus ostreatus L. Add to oxamyl pesticide as } \\
\text { additives and has ability to immobilizes } 95 \% \text { of nematodes in one } \\
\text { hour, so it will fortified pesticide. }\end{array}$ \\
\hline $\begin{array}{l}\text { Cucum } \\
\text { ber }\end{array}$ & $\begin{array}{l}2 / 11 / 201 \\
6\end{array}$ & - & - & - & - & - & $\begin{array}{l}\text { There is no compounds have relationship with pesticides or } \\
\text { pesticides themselves }\end{array}$ \\
\hline $\begin{array}{l}\text { Cucum } \\
\text { ber }\end{array}$ & $\begin{array}{l}16 / 11 / 20 \\
16\end{array}$ & - & - & - & - & - & $\begin{array}{l}\text { There is no compounds have relationship with pesticides or } \\
\text { pesticides themselves }\end{array}$ \\
\hline $\begin{array}{l}\text { Cucum } \\
\text { ber }\end{array}$ & $\begin{array}{l}23 / 11 / 20 \\
16\end{array}$ & - & - & - & - & - & $\begin{array}{l}\text { There is no compounds have relationship with pesticides or } \\
\text { pesticides themselves }\end{array}$ \\
\hline
\end{tabular}

\section{2,3 butanediol}

According to [11], it has been discovered that determinant aqueous insecticidal composition based on combined with surfactant, inorganic carrier, antifreeze agent, insecticide of neonicotinoid, will form class of strong stable components. The additives will improve flow ability, good adherence to plant propagation material, dust-off, and excellent performance on cold or frozen seeds. Kind of neonicotinoid that is used for this purposes is imidacloprid. The aqueous insecticide comprises about $25 \%$ of at least one component of antifreeze, 
for example 2,3 butanediol. Due to [12], ethanol, that is one of imidacloprid solvents, when it meet 2,3 butanediol, the mixture will become toxic to rats, so the mixture has toxic properties.

\section{Acetamiprid}

Kind of neonicotinoid insecticide, used for combating aphides and whitefly. The insecticide used widely in vegetables farms and has the same mode of action of imidacloprid[14].

\section{1,3,4-thiadiazole}

Compound used in the process of production pesticide against Rhizoctonia solani pest [15].

\section{formamide}

Oxamyl degradation happed by two pathway: hydrolysis to the oximino compound or enzymatic conversion via DMCF (dimethyl cyanoformamide) to N,N-dimethyloxamic acid. So formamide, is one of the compounds that forming the metabolism enzyme that is able for degrade oxamyl. It's existence clear evidence for complete degradation of active ingredients of oxamyl pesticide[16]. Formamide considered as irritant substance for respiratory system when analyte, it has median lethal dose $\left(\mathrm{LD}_{50}\right)$ of $>5,577 \mathrm{mg} / \mathrm{kg}$ and no observed adverse effective level (NOAEL) of $113 \mathrm{mg} / \mathrm{kg} /$ day. So it has toxic proparity[17].

\section{3-Butenoic acid, ethyl ester}

According to [18], the compound 3-Butenoic acid, ethyl ester has pesticide properties because it is able to combatant pests.

\section{Allyl vinyl ether}

As [19] reference mentioned that Allyl vinyl ether is one of oxamyl components that are represent caprolactam and/or caprolactam derivatives.

\section{t-Butyl ethylideneamine}

According to [20], herbicide, fungicides, insecticides, miticides, acaricides, and nematocides are broadly used in agriculture. pesticides contain adjuvant like surfactants to improve the handling of active ingredients and develop the composition of pesticide. Oxamyl and imidacloprid pesticides are one of the pesticides that this compound add to them for the mentioned purpose. It support some water condition to pesticide like chelating agent.

\section{Shellsol 140}

Due to [21], shellsol 140, is one of the organic solvents that could be used for liquefying pesticides for example oxamyl from carbamate pesticides. Reference [22], mentioned that, shellsol, is one of the solvent systems consist of aromatic hydrocarbons used to make active ingredients for pesticides like imidacloprid available for plants.

\section{1-Hexene}

As reference [23] mentioned that, hexene, is one of the organic solvents that are used in emulsifier pesticides like imidacloprid. It is one of the important compounds that is used in control release of imidacloprid pesticide active ingredients for prolong activity purposes .

\section{Heksan}

According to [24], heksan, is one of the organic solvents used for dilute imidacloprid pesticide. It is also used for mitigate the rate of imidacloprid photo degradation for prolong the duration life of imidacloprid impact.

\section{Diheptyl phthalate}

Diheptyl phthalate, is compound add to imidacloprid pesticide to reduce the degradation of pesticide by oxidation. It is considered as plasticizers components that add kind of elasticity to pesticide [25].

\section{Octamethylene glycol}

Due to the reference [26], this compound is add for low formation of foam for enhancing the reaction between water and imidacloprid pesticide when the farmer dilute it to reach the recommended concentration for application.

\section{Nonyl chloroacetate}

Compound used in preparing 6-(5-chloropyridin-2-yl)-2-pent-2-ynyl-4,5-dihydropyridazin-3(2H)-one. The latest compound add to imidacloprid pesticide for synergism purposes. The compound allow for the reaction to be slowly acclimatized with ambient temperature for putting aside any molecular destruction [27]. 


\section{Farnesol}

Compound add to imidacloprid for increase the pesticide ability for killing pest. There is significant relationship between increase the concentration of the compound and the efficiency of pesticide [28].

\section{Di-tert-butyldiazene}

Compound belong to azithiram pesticide, this pesticide belong to carbamate group, so it has the same mode of action[29].

\section{Caprolactam}

Represent polyester amide, it is biodegradable substance add to oxamyl and imidacloprid pesticide as plant treatment agent for improving the composition of pesticides[30, 31].

\section{Tetrahydrofurfuryl chloride}

Compound used in the production of clothianidin insecticide, it has the same mode of action of imidacloprid[32].

\section{Hexadecanoic acid}

Compound has toxicity to nematodes, so it is successfully used as nematocides like oxamyl and could be add to oxamyl for synergism purposes [33]. According to reference [34], plant Brassica juncea L. produce this compound when it will be under stress of imidacloprid.

\section{Isobutanol}

Compound add to imidacloprid and oxamyl pesticides for rapid uptake of active ingrediants by plants, better distribution of pesticide inside the plant and soil, and prevent any injury that maybe happed to the plants due to the effect of pesticides[35].

\section{2,2-Dimethyl pentane}

Organic solvent used with oxamyl and imidacloprid pesticide for producing lignin-based matrix microparticles for the controlled release of an agricultural active ingredients includes forming an emulsion of an organic solution in an aqueous solution [23].

\section{Dibutyl phthalate}

compound add to oxamyl and imidacloprid pesticide for preventing volatilization, crystallization, and precipitation of active ingredients for more effectiveness of pesticide in killing pest. It is also used to anti fouling compounds which play important role in conservation environment by preventing adherence of pesticide compounds with water for increase the ability of decomposers for decomposition [36 , 37].

\section{Oleamide}

This compound has great impact in inhibiting acetylcholinesterase enzyme. so it is add to oxamyl for fortified pesticide impact. The compound has ability for blocking connexin by long chain of alcohol found inside the structural formula. Connexin is class of transmembrane proteins that form assembled structures in vertebrates [38].

\section{3-Heptadecanol}

Kind of fatty alcohol, used as drift control agent that is add to pesticides like oxamyl and imidacloprid [39].

Glycerol

Substance used in the process of preparing pesticide intermediate acrolein by using glycerol [40].

\section{Hexadecanal}

Compound add to oxamyl and imidacloprid pesticide as insecticide attractant and killing agent. It increase the performance of insecticides in control pests[41].

\section{2,13-Octadecadienal}

compound classified as pheromones or insecticidal active compounds produced by the plant naturally. It add to pesticides like imidacloprid or oxamyl as attractive material [42].

\section{9,12,15 Octadecatrienal}

It is kind of insect pheromones add to imidacloprid pesticide for integrated pest management issue[43]. 


\section{2-Methyl butyl butyrate}

This compound represent Wheat germ alcohol extracts, they play important role as feeding attractant for larvae of Spodoplera lilurae L. It is add to many pesticides like oxamyl for their high ability in attract pests and that will fortifying the pesticide ability in killing pest[44]

1-cyclohexylethylamine

One of the amide compounds that shows excellent ability in controlling insect pests. It add to many pesticides and oxamyl is one of them[45].

\section{Dodecanal}

Is insect pheromones add to most carbamate pesticides as addatives. it is sexual pheromones able to make sexual disruption and reduce the population of insect pest[46].

\section{Di-methylformamide}

One of the solvents that are used to make oxamyl pesticide able to be up take by plant or soil[47].

\section{Tridecanoic acid}

The compound add to imidacloprid and oxamyl pesticide as anion surfactant. it will help in reduce the surface tension of liquid pesticide and that will serve for more diffusion [48]

\section{E-9-Tetradecenal}

substance produce by the plant add to pesticides like oxamyl and imidacloprid because this substance classified as pheromones, kairomones that defined as any substance that is produced by individual species for the advantages of other different recipient species or attractants [49].

\section{2,13-octadecadien-1-ol}

compound classified as pheromones or insecticidal active compounds produced by the plant naturally. It add to pesticides like imidacloprid or oxamyl as attractive material [50].

\section{E-11-Hexadecenal}

substance classified as classified as pheromones, kairomones that defined as any substance that is produced by individual species for the advantages of other different recipient species or attractants add to pesticides for fortification purposes [41].

\section{Di isopropyl sulfite}

This compound is used in the Process for the preparation of pesticide-comprising aqueous polymer dispersions With an average particle size of the dispersed particles of $<1000 \mathrm{~nm}$ by radical polymerization of an oil-in-Water emulsion, In order to modify the properties of the polymers, we used Di isopropyl sulfite for that purpose. the compound is used in the process of production oxamyl and imidacloprid pesticide [51].

\section{9,11-Dodecadien-1-ol}

Compound add to imidacloprid pesticide to increase the dispersion of pesticide inside the environment applied and that will increase the activity of pesticide in killing pest [52].

\section{Dodecanoic acid and Decanoic acid}

The compound represent bio-toxin, purified from Pleurotus ostreatus L. fungus. Add to oxamyl pesticide as additives. It has the ability for immobilizes $95 \%$ of nematodes within one hour, so it will increase the control of pesticide on pests[53].

\section{Undecanal}

Fragrances synthetic add to imidacloprid pesticides and oxamyl to increase foliar penetration of active ingredients or create formulation of baits for pests[54].

\section{Nonadecanoic acid}

The compound represent monocarboxylic acids. It is kind of fatty acids that is add to oxamyl and imidacloprid pesticides for formation suspension belong to active ingredients of both pesticides [55].

\section{4-Methyloctanoic acid}

Compound represent polyhydroxyalkanoates.It is add to oxamyl and imidacloprid as kind of solid shape plant treatment. the compound facilitate the process of fusion between the active ingredient of pesticides and plant sap for systematic treatment with pesticides[56].

\section{E-11-Tetradecenoic acid} better effect[57].

Preservatives, add to imidacloprid pesticide for delay the fast decomposition process of pesticide for

\section{9-Octadecenoic acid}

kind of fatty acid add to imidacloprid pesticide as attractant. It showed ability for attract whitefly to any desired location, so it will fortified imidacloprid pesticide[58].

\section{Discussion Of GC/MS Results}

The results of GC/MS, shows that the collection from November months is the better one because all kinds of pesticides and pesticides bi-products have been decomposed. The reason for that return back to the kind of agriculture applied, greenhouse kind of agriculture is applied in this month. According to reference [59], five 
important factors affect the rate of decomposition that is happed by micro-organisms decomposer: temperature, aeration, soil pH, soil moisture, and C:N ratio. The highest average of temperature in Iraq reaches to $37.41^{\circ} \mathrm{C}$ in hottest months but there is high fluctuation in the temperatures between morning, afternoon, evening and night [60]. The optimal temperature for working micro-organisms decomposer is $30-40{ }^{\circ} \mathrm{c}$ but the high fluctuation retard the decomposition process [59]. So this is the reason for fully decomposition for active ingredients for pesticides applied during life-cycle of targeted vegetables including the most important two pesticides that are used in planting vegetables, oxamyl and imidacloprid. But the high fluctuation in temperature do not let the decomposers done their work, that was happed in exposed kind of agriculture months, August, September, and October. but in greenhouse kind of agriculture that is happed in November, the plastic cover prevent the fluctuation of temperature due to it's ability for reverse the infrared beams that are coming from sun and return it back to soil and prevent the dispersion of them will keep the soil warm during the night and other equipments add to greenhouse that prevent the fluctuation of temperature. Best moisture soil contain for the optimal work of decomposers is 60 to 80 percent of the water-holding capacity [59]. So greenhouse kind of agriculture can set the moisture contain of soil better than exposed agriculture due to less evaporation that is happed in greenhouse. About soil aeration, soil $\mathrm{pH}$ and $\mathrm{C}: \mathrm{N}$ ratio are the same in both kinds of agriculture because the farmer use the same field in both kinds of agriculture but the difference in plastic mulch. Aeration in both kinds of agriculture are served in optimal way and C:N ratio are kept in optimal ratio by fertilizers. Photo degradation water degradation of pesticide have grate impact on increase the rate of degradation in both kinds of agriculture [61 62]. The half-life of imidacloprid and oxamyl in tomato fruits (kind of vegetables) were 2.88,3.12, and 3.46 days after 12 days from application[63]. Our targeted vegetables are ephemeral plants, so their life cycle ended in 1-3 months. So before the targeted plants harvested, the concentration of pesticide reduced to half the concentration when it apply to plant, that is another reason of disappearing oxamyl and imidacloprid active ingredients in all samples. According to reference [64], imidacloprid can bind with soil organic matter and that reduce potentially the ability of imidacloprid for leaching throw the soil, this explain the reason of high ability for decomposers for degrade the active ingredients of imidacloprid.

The samples 29/8/2016, zucchini from Sulaimaniyah and 24/8/2016, eggplant from Al-Yusufiyah, showed no pesticide residues or pesticide bi-products residues, the investigation revealed that the kind of planting soil is sandy soil. Sand soil has ability for leaching imidacloprid up to $97 \%$, so this is the reason of disappearing pesticides and pesticides bi-products[65, 66].

The commercial formulation of imidacloprid pesticides contain components increase the leaching rate of active ingredients belong to pesticide more than their normal rate for environmental conservation purposes. When temperature reach to $20^{\circ} \mathrm{C}$, the rate of imidacloprid solubility in water increase 610 higher than other circumstances with aqueous photolysis reach to 0.2 faster and water-sediment reach to 129 slower than other condition, this also explain the reason for disappear imidacloprid from November samples [66].

Oxamyl showed low persistence in the soil, the half-life for pesticide is 4-20 days[67]. Reduction is due to decomposition by aerobic and anaerobic bacteria[68]. Oxamyl decay rapidly in alkaline soils and more slowly in acidic soils[69]. Oxamyl does not bind or adsorb to soil particles, but it has ability to leach in soil[67, 69]. Oxamyl has strong adsorption in soils contain high concentration of organic matter, but their adsorption is week in sandy loam. any increase in temperature level make decrease in adsorption[70].

Due to the high ability of bacteria for decompose oxamyl, it is found rarely in surface water and frequently in ground water[71]. Oxamyl residual duration life in plants are 1-2 weeks. It is considered non toxic for plants[72]. Oxamyl metabolized rapidly by plants and can translocate easily in plant parts[69].

\section{Conclusion}

We can conclude that the targeted local Iraqi vegetables are healthy vegetables because the GC/MS results shows no pesticide residues and the existence of only pesticides bi-products. The degradation rate for pesticides are high in Iraqi soil, that reverse in best way on Iraq people's health. The greenhouse kind of agriculture is much better than exposed kind of agriculture. Despite the fact that our targeted pesticides, oxamyl and imidacloprid, are highly hazardous and moderate hazardous consequently. They look like safe to be used for agricultural purposes due to their short half-life and high ability for degradation. Some of the bi-products that appeared in GC/MS results, are safe for human health because they are natural compounds found in the plants, the other shows kind of hazardous, due to their toxicity or become toxic when they are combine with some compounds available inside the pesticide mixture.

\section{References}

[1] Y. Hu, Y. H. Chiu, R. Hauser, J. Chavarro, and Q. Sun, "Overall and class-specific scores of pesticide residues from fruits and vegetables as a tool to rank intake of pesticide residues in United States: A validation study," Environ. Int., vol. 92-93, no. May, pp. 294-300, 2016.

G. Book, "Compendium of Chemical Terminology," International Union of Pure and Applied Chemistry, 2014, p. 528. 
[3] S. STEVENSON, F. J.; KAUFMAN, D.; STILL, G.; PAULSON, G.; BANDAL, "Bound and conjugated pesticide residues," ACS Symp. Ser., p. 180, 1976

[4] F. Zhang, C. Yu, W. Wang, R. Fan, Z. Zhang, and Y. Guo, "Rapid simultaneous screening and identification of multiple pesticide residues in vegetables," Anal. Chim. Acta, vol. 757, no. December 2012, pp. 39-47, 2012.

[5] G. Marrazza, "Piezoelectric biosensors for organophosphate and carbamate pesticides: A review," Biosensors, vol. 4, no. 3, pp. 301-317, 2014.

[6] B. Łozowicka, M. Jankowska, and P. Kaczyński, "Pesticide residues in Brassica vegetables and exposure assessment of consumers," Food Control, vol. 25, no. 2, pp. 561-575, 2012.

[7] F. Diop, A., Diop, Y. M., Thiaré, D. D., Cazier, F., Sarr, S. O., Kasprowiak, A., ... \& Delattre, "Monitoring survey of the use patterns and pesticide residues on vegetables in the Niayes zone, Senegal," Chemosphere, vol. 144, pp. 1715-1721, 2016.

[8] H. Kwon, S. J. Lehotay, and L. Geis-Asteggiante, "Variability of matrix effects in liquid and gas chromatography-mass spectrometry analysis of pesticide residues after QuEChERS sample preparation of different food crops," J. Chromatogr. A, vol. 1270, pp. 235-245, 2012.

[9] G. T. Bakırcı, D. B. Yaman Acay, F. Bakırcı, and S. Ötleş, "Pesticide residues in fruits and vegetables from the Aegean region, Turkey," Food Chem., vol. 160, pp. 379-392, 2014.

[10] P. Sivaperumal, P. Anand, and L. Riddhi, "Rapid determination of pesticide residues in fruits and vegetables, using ultra-highperformance liquid chromatography/time-of-flight mass spectrometry," Food Chem., vol. 168, pp. 356-365, 2015.

[11] R. Schlatter, C., \& Ramachandran, “( 19 ) United States,” 2008.

[12] F. Poldrugo, S. Barker, M. Basa, and F. Mallardi, "Ethanol Potentiates the Toxic Effects of 1,4=Butanediol," vol. 9, no. 6, 1985.

[13] K. Gleason, "How to convert Centrifuge RPM to RCF or G- force," Lab Ski. Res., 2012.

[14] S. Saha, R. Mondal, and S. Mukherjee, "Persistence of acetamiprid in paddy and soil under West Bengal agro-climatic conditions," 2017.

[15] Y. Chen, H., Li, Z., \& Han, "Synthesis and Fungicidal Activity against Rhizoctonia s olani of 2-Alkyl (Alkylthio)-5-pyrazolyl-1, 3, 4-oxadiazoles (Thiadiazoles).," J. Agric. Food Chem., vol. 48, no. 11, pp. 5312-5315, 2000

[16] J. C. Harvey Jr, J., \& Han, "Metabolism of oxamyl and selected metabolites in the rat," J. Agric. Food Chem., vol. 26, no. (4), pp. 902-910, 1978.

[17] H. Kim, "근로자 건강 유해성과 위험성 평가 Worker Health Hazard and Risk Assessment of Formamide using in Workplaces in South Korea," vol. 20, no. 2, pp. 35-42, 2016.

[18] O. Meyer, W., Drabek, J., Farooq, S., Gsell, L., \& Kristiansen, “No T,” U.S. Patent No. 4,161,535., 1979.

[19] C. Sowa, M. M. Walter, and N. C. Us, “( 19 ) United States $4{ }^{\circ \circ}{ }^{\circ}{ }^{\circ}$ NR ${ }^{\circ}$ E ROAD,” no. 19, 2009.

[20] A. Modaressi, H., \& Douglass, "No Titl,” U.S. Patent No. 8,383,137, 2013.

[21] U. Taranta, C., Meier, W., Strauss, K., Kraushaar, A., \& Steinbrenner, "No Title,” U.S. Patent No. 8,178,117.

[22] K. Bergstrom, “(19) United States (12)," vol. 1, no. 19, 2014

[23] S. R. Yearla and K. Padmasree, "Exploitation of subabul stem lignin as a matrix in controlled release agrochemical nanoformulations : a case study with herbicide diuron,” Environ. Sci. Pollut. Res., 2016.

[24] K. Kalister, "UNIVERZA V NOVI GORICI," 2011.

[25] V. Guzsvany, Z. Papp, Š. Ivan, and V. Guzsvány, "Voltammetric determination of imidacloprid insecticide in selected samples using a carbon paste electrode Voltammetric determination of imidacloprid insecticide in selected samples using a carbon paste electrode," no. June, 2015.

[26] S. Baur, P., Auler, T., Deckwer, R., \& Giessler, "No Titl," U.S. Patent No. 9,215,868., 2015.

[27] D. H. Kelly, M., Ross Jr, R., \& Young, "2-alkynyl-6-pyridin-2-yl-pyridazinones, 2-alkynyl-6-pyridin-2-yl-dihydropyridazinones, 2alkynyl-6-pyrimidin-2-yl-pyridazinones and 2-alkynyl-6-pyrimidin-2-yl-dihydropyridazinones and their use as fungicides," U.S. Patent No. 8,426,412., 2013.

[28] L. Tang, X., Chen, S., \& Wang, "Isolation and Insecticidal Activity of Farnesol from Stellera chamaejasme," Asian J. Chem., vol. 23, no. 3, p. 87720208, 2011.

[29] J. J. Pignatello, "Degradation of pesticides by ferric reagents and peroxide in the presence of light," U.S. Patent No. 5,232,484, 1993.

[30] O. U. P. Joachim Simon, Dl'isseldorf; Hams Peter Ml'illel' and B. G. an of (DE) Solingen; Hans-Georg Rast, "PLANTTREATMENT AGENTS," US 6,191,071 B1, 2001.

[31] O. U. P. Joachim Simon, Dl'isseldorf; Hams Peter Ml'illel' and B. G. an of (DE) Solingen; Hans-Georg Rast, "PLANTTREATMENT AGENTS," 2001.

[32] S. Kagabu, M. Hibi, and K. Nishimura, "Prodrug-Oriented Molecular Design of Neonicotinoids: Preparation of ImidaclopridDerivatives and Their Insecticidal Activity Prodrug-Oriented Molecular Design of Neonicotinoids : Preparation of," vol. 8451, no. February 2017, 2014.

[33] D. Weisleder, “A NEMATICIDAL TOXIN FROM Pleurotus ostreatus,” vol. 18, no. 2, pp. 127-136, 1992.

[34] "24-Epibrassinolide induces the synthesis of phytochemicals effected by imidacloprid pesticide stress in Brassica juncea L," no. September, 2015.

[35] J. Glayne D. Doolittle, "METHOD FOR APPLICATION OF PESTICIDES AND PLANT GROWTH REGULATORS AND NUTRIENTS TO PLANTS," 2014.

[36] F. Kugler, M., Londershausen, M., Schrage, H., Uhr, H., \& Kunisch, “ANTI-FOULING COMPOSITIONS,” U.S. Patent No. $5,990,043,1999$.

[37] V. Guzsvany, Z. Papp, Š. Ivan, and V. Guzsvány, "Voltammetric determination of imidacloprid insecticide in selected samples using a carbon paste electrode Voltammetric determination of imidacloprid insecticide in selected samples using a carbon paste electrode," no. June, 2015.

[38] M. Mouthon, F., \& Charveriat, "Use of anti-connexin agents for enhancing the therapeutic effect of acetylcholinesterase inhibitors," $14 / 355,153,2012$.

[39] S. L. Goyal, R., Shanmuga, K., \& Wilson, “Agricultural pesticide compositions,” Patent Application No. 14/585,440., 2014.

[40] Z. H. A. N. G. Yue, "Study on Preparing of Pesticide Intermediate Acrolein with Biological Glycerol,” J. Anhui Agric. Sci., vol. 4, p. $18,2009$.

[41] J. Losel, P., Penners, G., \& Weissmuller, "INSECTICIDAL ATTRACT-AND-KILL FORMULATIONS," U.S. Patent No. 5,707,638., 1998 .

[42] M. Gewehr, "Pesticidal mixtures comprising jasmonic acid or a derivative thereof," U.S. Patent Application No. 14/432,503., 2013.

[43] Pests and Pathogens : Management Strategies, no. September. 2014. 
[44] E. Yang, "FEEDING ATtRACTANT OF SPODOPTERA LitURAE LARVA AND USE THEREOF," Pub. N0.: US 2014/0212375 A1, 2014.

[45] M. Kurahfdshia, "AMIDE COMPOUNDS AND USE THEREOF FOR PlANT DISEASE CONTROL," Pub. No.: US 2010/0298391 A1, 2010.

[46] C. A. Light, D. M., \& Henrick, "Bisexual attractants, aggregants and arrestants for adults and larvae of codling moth and other species of lepidoptera," U.S. Patent No. 6,528,049, 2003.

[47] L. Kennedy, “Acute Toxicity Studies with Oxamyl," pp. 423-429, 1986

[48] N. Inoue, "Termiticide and preparation containing same.," U.S. Patent Application No. 14/781,119, 2014.

[49] J. Losel, P., Penners, G., \& Weissmuller, “'Insecticidal attract-and-kill formulations.,"” U.S. Patent No. 5,707,638., 1998

[50] M. Gewehr, "Pesticidal mixtures comprising jasmonic acid or a derivative thereof," U.S. Patent Application No. 14/432,503., 2013.

[51] F. C. Dyllick-Brenzinger, R., Bratz, M., Kruger, C., Oetter, G., \& Gorth, “'Method For Producing Aqueous Polymer Dispersions Containing Pesticides And Use Thereof.," U.S. Patent Application No. 11/908,234., 2006.

[52] J. Sieverding, E., Hintz, S., Dambacher, T., Beckerath, T., \& Busch, "Water-in-oil polymer dispersion as additive in active ingredient-comprising compositions.," U.S. Patent Application No. 10/216,131, 2012.

[53] D. Weisleder, “A NEMATICIDAL TOXIN FROM Pleurotus ostreatus,” vol. 18, no. 2, pp. 127-136, 1992.

[54] G. Huchet, K. S. Us, C. Letmathe, B. Gladbach, A. Eble, and B. De, "( 12 ) United States Patent Rosenfeldt et a ]. Fungicides :," vol. 2 , no. 12,2012

[55] P. Vermeer, R., \& Baur, “'Suspension concentrates.,” U.S. Patent No. 7,977,278., 2011.

[56] S. Tsuboi, S. I., Kamochi, A., Yamashita, N., Saito, I., Wada, Y., Isono, K., \& Koyama, “'Plant treatment agents., ” U.S. Patent No. 6,063,393., 2000.

[57] T. Kollars, "FORMULATIONS AND DEVICES FOR DELIVERING COMPOUNDS TO ARTHROPODS AND MICROORGANISMS WITHIN ARTHOPODS," 2010

[58] J. G. C. Hamilton, “'Insect attractants and their use in methods of insect control.,"” U.S. Patent No. 8,586,068, 2013.

[59] "Factors Influencing rate of Organic Matter Decomposition."

[60] S. Zakaria, N. Al-ansari, and S. Knutsson, "Historical and Future Climatic Change Scenarios for Temperature and Rainfall for Iraq," vol. 7, no. 12, pp. 1574-1594, 2013.

[61] J. Fenoll, P. Flores, P. Hellín, C. María, and S. Navarro, "Photodegradation of eight miscellaneous pesticides in drinking water after treatment with semiconductor materials under sunlight at pilot plant scale," vol. 206, pp. 54-64, 2012.

[62] S. Nasseri, N. Rastkari, M. Shayeghi, and V. Control, "Degradation of Organophosphorus Pesticides in Water during UV / H 2 O 2 Treatment : Role of Sulphate and Bicarbonate Ions,” vol. 9, no. 4, pp. 2015-2022, 2015

[63] E. Benzoate, "Residues and Dissipation of Imidacloprid, Oxamyl, and Emamectin Benzoate in Greenhouse Grown Tomato Fruits and Their Influence on Lycopene Content," 2015.

[64] J. Bonmatin, C. Giorio, V. Girolami, D. Goulson, and D. P. Kreutzweiser, "Environmental fate and exposure; neonicotinoids and fipronil," pp. 35-67, 2015.

[65] H. M. Selim, C. Y. Jeong, and T. A. Elbana, "Transport of Imidacloprid in Soils : Miscible Displacement Experiments," vol. 175, no. 8, pp. 375-381, 2010.

[66] J. Bonmatin, C. Giorio, V. Girolami, D. Goulson, and D. P. Kreutzweiser, "Environmental fate and exposure; neonicotinoids and fipronil," pp. 35-67, 2015.

[67] J. P. Wauchope, R. D., Buttler, T. M., Hornsby, A. G., Augustijn-Beckers, P. W., \& Burt, "The SCS/ARS/CES pesticide properties database for environmental decision-making," Rev. Environ. Contam. Toxicol., vol. 123, pp. 1-155, 1992.

[68] R. J. Wagenet, L. P., Lemley, A. T., \& Wagenet, "A review of physical-chemical parameters related to the soil and groundwater fate of selected pesticides used in New York State," Search Agric. univ. Agr. exp. sta., New York state Coll. Agric. life Sci., 1985.

[69] "Health Advisory Summary: U.S. Environmental Protection Agency, Health advisory summary: Oxamyl. Office of Drinking water" Washington D.C., 1987.

[70] R. J. Wagenet, L. P., Lemley, A. T., \& Wagenet, "A review of physical-chemical parameters related to the soil and groundwater fate of selected pesticides used in New York State," Search Agric. univ. Agr. exp. sta., New York state Coll. Agric. life Sci., 1985.

[71] S. Z. Cohen, C. Eiden, and M. N. Lorber, "Monitoring Ground Water for Pesticides," 1986.

[72] D. R. Kidd, H., \& James, The agrochemicals handbook. 1991.

Maad N. Mahdi. "Detection of Oxamyl and Imidacloprid Pesticide residues in Some Iraqi Vegetables." IOSR Journal of Agriculture and Veterinary Science (IOSR-JAVS) 10.7 (2017): 67-80. 